\title{
Research on indoor sex work in Poland - an ethnographer's dilemmas
}

Ślęzak, I., 2018. Research on indoor sex work in Poland - an ethnographer's dilemmas. Oñati Socio-legal Series [online], 8 (8), 1134-1150. Received: 14-07-2017; Accepted: 07-06-2018. Available from: https://doi.org/10.35295/osls.iisl/0000-0000-0000-0988

\begin{abstract}
In this article, I would like to present selected dilemmas connected with conducting empirical sociological studies of indoor sex work in Poland. The dilemmas result from the social, cultural and legal context in which escort agencies operate. The impact of different dimensions of the context is visible both at the level of actions undertaken by escort agency managers and workers as well as the researcher's opportunities and possibilities for data collection. My considerations are based on qualitative field research which I carried out between 2007 and 2013, at four premises, so-called escort agencies, operating in the Polish city of Lodz. The article will start with an explanation of what escort agencies are, and with a brief outline of the Polish legal provisions related to prostitution, with special emphasis on the situation of escort agencies. I will then characterize the research project briefly, and present some of the challenges posed during its realization.
\end{abstract}

\section{Key words}

Escort agency; indoor sex work; qualitative research; ethnography

\section{Resumen}

El artículo expone algunos dilemas propios de la realización de un estudio sociológico empírico en Polonia sobre trabajo sexual en interiores. Los dilemas provienen del contexto social, cultural y jurídico en el que operan las agencias de acompañantes. El impacto de las diferentes dimensiones del contexto se percibe tanto en las acciones de los responsables de las agencias como en las oportunidades y posibilidades que tiene la investigadora para obtener información. Mis consideraciones se basan en la investigación cualitativa de campo que realicé entre 2007 y 2013, en cuatro agencias de acompañantes de la ciudad de Lodz. El artículo comienza con una explicación de qué son las agencias de acompañantes y con unas pinceladas sobre las normas jurídicas polacas sobre prostitución, con especial atención a la situación de las agencias de acompañantes. Después, definiré brevemente el proyecto de

\footnotetext{
* Izabela Ślęzak, PhD, Assistant Professor in the Department of Sociology of Organization and Management, Institute of Sociology, Faculty of Economics and Sociology of the University of Lodz. Main spheres of scientific interests focus on methodology of social research, especially qualitative methods, symbolic interactionism, sociology of work and organization. Currently performing field studies related to the phenomenon of sex work. Postal address: Department of Sociology of Organization and Management, Institute of Sociology, Faculty of Economics and Sociology. University of Lodz. ul. Rewolucji 1905r. Nr 41/43. 90-214 Lodz, Poland. Email address: iza.slezak@gmail.com
}

\section{(cc) EY-NC-ND}

Oñati International Institute for the Sociology of Law AntiguaUniversidad s/n - Apdo.28 20560 Oñati - Gipuzkoa - Spain 
investigación y expondré algunas de las dificultades que se presentaron en su transcurso.

\section{Palabras clave}

Agencia de acompañantes; trabajo sexual en interior; investigación cualitativa; etnografía 


\section{Table of contents / Índice}

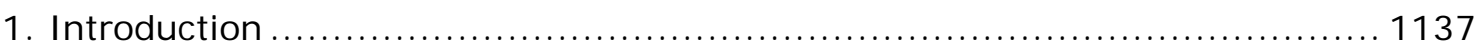

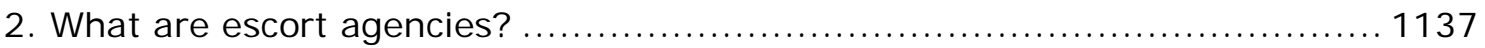

3. Legal context of the research - escort agencies and Polish law ................ 1139

4. Challenges related to carrying out the research project ...................... 1140

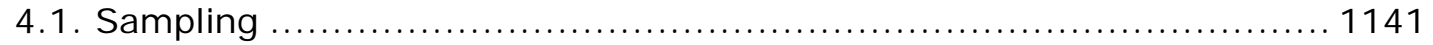

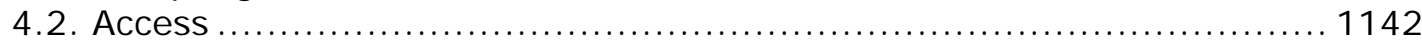

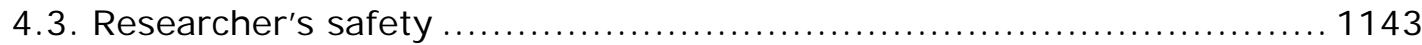

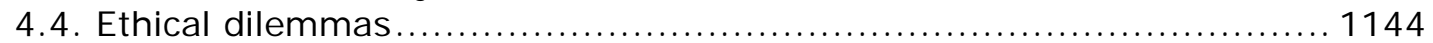

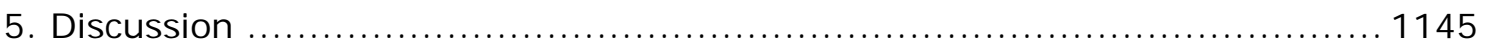

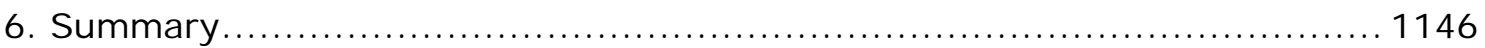

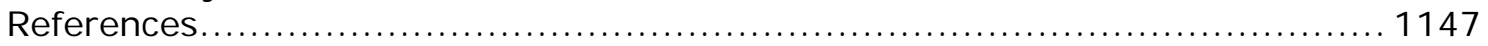




\section{I ntroduction}

Conducting research project on escort agencies (or more broadly, indoor sex work) implies many challenges for the researcher. These organizations are reluctant to reveal information, which is the result of the social, cultural and legal context of their operation. In Poland, escort agencies are criminalized, and their employees (mainly female sex workers) experience social stigma (Goffman 1963). Therefore, any researcher starting a research project has to work out ways to establish a rapport and gather the data in spite of these difficulties. In the article, I will present the dilemmas and challenges that I experienced while conducting research on indoor sex work in Poland. Based on my own research experience, I will also present how I tried to overcome them.

The empirical basis of the article is ethnographic research (Hammersley and Atkinson 2000, Atkinson et al. 2001, Kleinknecht 2007, Angrosino 2010) which I carried out between 2007 and 2013, at four premises, so-called escort agencies, operating in the Polish city of Lodz (Ślęzak 2016). They are a part of the ethnographic tradition of research of the phenomenon of prostitution carried out from the Chicago School (e.g. Reckless 1925, 1933), up to contemporary times (e.g. Prus and Irini 1988).

The article will start with an explanation of what escort agencies are, and with a brief outline of the Polish legal provisions related to prostitution, with special emphasis on the situation of escort agencies. Afterwards, I will describe the research project briefly, and present selected questions which posed a challenge for me during its realization. I will also describe the ways in which I tried to overcome the difficulties encountered in the field. I will finish the article with a summary, which will present more general conclusions resulting from my own research experiences.

\section{What are escort agencies? ${ }^{1}$}

As regards historical circumstances and the contemporary legal, social and cultural context, the sector of paid sex services develops quite differently in each country. As a consequence, at first sight, similar organizational forms of prostitution have their own local specificity, and they often differ significantly from one another. An example of such a specific type of indoor sex work in Poland is escort agencies. They are a kind of brothel, offering their visitors sexual services (although unofficially) on the premises, at the client's place or in a hotel. In the research city, the market for such agencies is relatively differentiated. Some of them are located in detached houses, others in apartments or tenement houses. They are often marked with a neon sign and a signboard, although it is not always clear enough to let the passers-by identify the place's purpose. Some of them operate on the outskirts of the city, in quiet, uninhabited locations, others in the city center - where the clients can get to easily and comfortably. Several agencies in the city have operated in the same location for a number of years, though the administrators have changed multiple times. Keeping the same address allows the next owner/tenant to use the premises' infrastructure (e.g. poles, lighting and monitoring systems) and thus reduce investment expenditures. The old address is also better remembered by clients, which brings benefits when they are searching for commercial sexual services.

The operating agencies differ with the level of preparation of the physical space for the specificity of the provided services. According to my observations, the best agencies' interiors are especially adapted to such activities. The central, and at the same time the representative part of an agency is the lounge, where the clients start their visit. There are poles for dancing and a bar with alcohol. Apart from the lounge, there are also rooms, from a few to a dozen or so (all of which should have a separate bathroom with a shower or bath), devoted to intimate meetings between the clients and the women. The rooms and the lounge are the only places in the agency which

${ }^{1}$ The subchapter is based on data that I gathered as a part of a research project that is characterized in more detail in a further part of the article. 
the clients have access to. The remaining part of the agency is occupied by areas only for the workers: rooms for the women where they get changed, wait for the clients, or simply live, a bathroom and a kitchen for the employers, and a room for the security guards and the manager. Agencies usually hire from a few to several dozen women. These agencies operate mainly at night; however, some of them accept clients only during the day.

Small agencies, located in apartments, usually look more modest. They operate primarily during the day, potentially until late night, in order not to disturb the peace (thus causing conflicts) with the other residents of the block of flats. As they often change their location, they are not adapted to the specific requirements of the sex business, and they look like ordinary apartments despite playing a different function. Particular rooms are used for meetings with clients. The kitchen or one of the rooms plays the function of a staff room. The same bathroom is available both to the clients and the female workers. These apartments usually do not offer additional attractions (a mini-bar, a pole for dancing). Taking into account those inconveniences, prices for the meetings are lower than in the agencies.

Within the scope of my research project, I was predominantly interested in the premises of the first type.

As agencies are usually located within housing estates, among blocks of flats or detached houses, attention should be paid to their relationships with their close surroundings. As my studies suggest, there were not usually any negative reactions to the operation of an agency in the immediate vicinity. These relationships may be described as quiet acceptance, especially if the agency had operated in the same area for years, and co-existence principles had consolidated. It needs to be emphasized that the neighborhood may also benefit from the agency's operations (e.g. workers may become regular customers of local stores or beauty salons). Hence, it may be assumed that social acceptance for the existence of such places is quite wide in Lodz.

Escort agencies are highly varied in terms of the level of security that they offer to their employees. The agency's manager has the greatest influence on whether women are relatively safe in a given place or more exposed to violence from clients and other workers of the agency. The results of my research suggest that agencies operating in Lodz may be ordered on a continuum from places managed in an oppressive manner to agencies where managers adopt a professional style (Ślęzak 2016). An oppressive manner of management means that bosses treat the agency as an organization that belongs to the criminal sphere. As a result, they accept violence, compulsion and exploitation as techniques for control over women providing sex services:

By the way, the boss called us names, which I didn't like at all: 'You morons, you idiots, you morons with no education', and I said to myself: 'Please, I graduated from such a school that it would knock your socks off'. But I stayed quiet. I said to myself: 'OK, I'm a moron with no education, I'm an idiot, but you still ride on my cunt' [ with anger]. Yeah, this finished me off the most.(Female sex worker, 30 years old, working at escort agencies for five years)

There is a boss, who is an alcoholic, and when he drinks too much, he beats the girls, because he unloads his aggression on these girls. He has two favorites, and the rest are treated very badly. (Female sex worker, working at escort agencies for two years)

In contrast, in professionally managed agencies, managers devote a lot of attention to improving the workers' safety. The main ways of managing workers are regulations and principles of work, but also financial penalties. There is no violence from managers; they try to prevent and eradicate any forms of violence from co-workers or clients. For this purpose, they install systems for monitoring and a quick alarm for security workers, which allows rapid response in case of violent incidents. An agency managed in such a manner is a much safer place for the provision of sex services, 
providing the workers with a certain level of stabilization for work conditions and rules.

There was this client here, and he started: 'You whores, fucking bitches'. And the girls were like: 'What? Are you talking to us?' 'Yeah'. So we went to our room. And the boss heard it. And he said: 'Sir, please leave, you won't insult the girls here'. So, such a boss is alright! And in other places they wouldn't pay attention to this, only MONEY matters. And here, I can't say that. They take care of us, and they pay attention. Such a client is asked to leave. (Female sex worker, 32 years old, working at escort agencies for two years)

J. [security worker] looks in the camera to check who it is and lets them enter or not. They already know it, so they more or less know who they can let in and who they can't, when a guy is aggressive, or there are two such guys, because he sees it, he's seen everything since the guy got to this street, our door, how the man is behaving. When he sees that a group of guys is not alright, he doesn't let them inside. They'll just keep calling and leave. (Female sex worker, working at escort agency for one week)

According to my observations, the situation of women who provide sex services in various types of facilities may be extremely different. However, from the perspective of Polish law, all such places, including those managed in a more professional manner, are breaking the law.

\section{Legal context of the research - escort agencies and Polish law}

The Polish legal system is constructed on the basis of abolitionist assumptions (Piórkowska-Flieger and Wala 2014). The legal solutions refer to the Convention for the Suppression of the Traffic in Persons and of the Exploitation of the Prostitution of Others, passed by the United Nations on 2 November 1949, and ratified by Poland in 1952. The Convention obliged the signatories to abolish any forms of rationing or registering, and the obligation to report for inspection by those people providing sexual services. It also obliged the ratifying states to abolish all contrary legal provisions, i.e., which punished prostitution as a crime or offense (Radecki 1968, p. 355). Pursuant to current Polish law, prostitution is not illegal, however, the actions of third parties are penalized, i.e., those who intend to encourage, facilitate, benefit or force prostitution (also human trafficking for the purpose of prostitution) [Arts. 203, $204 \S 1,204 \S 2,204 \S 3$ and $115 \S 22$ of the Criminal Procedure Code of Poland, 1997].

In the light of such legal provisions, the fact that there are numerous agencies functioning in Poland needs to be explained. Escort agencies are a special form of facilitating prostitution (Marek 2010, p. 467). However, to charge the agency's owner under criminal law, it needs to be proved that they acted in order to obtain financial gain (Piórkowska-Flieger and Wala 2014), which currently may be difficult, as the law enforcement agencies must have evidence (testimonies from the female workers). However, the workers decide to cooperate with the police very rarely (see: Kozłowska-Kalisz and Nazar-Gutowska 2014, Marczewski 2014), only in extreme situations, e.g., violence from the people operating the agency. Another reason for the free operation of escort agencies is the fact that their owners know how to comply artificially with legal provisions. Thus, the agencies have two faces: a legal, although superficial one, maintained for the needs of state institutions, and the proper, although illegal one (consisting in facilitating and deriving benefits from prostitution, and sometimes also in inducing someone to do it). In the case of the premises that I researched, their legal face was created through the registration of a business enterprise, e.g. in the form of a trading and service company, a motel, the provision of lonely hearts services or performing massages. Officially, agencies are companies that have nothing in common with activities forbidden by law. ${ }^{2}$ They hire employees, like every other legal company. Agreements include positions typical for the above-

\footnotetext{
${ }^{2}$ I refer only to those agencies where no people are forced into prostitution.
} 
mentioned branches, so the women work as cleaning ladies, receptionists, bartenders, dancers or masseurs, and they officially do not provide sex services (in some cases, they even sign a statement that they will not provide sexual services at work). However, it needs to be emphasized that the agencies pose an object of interest (sometimes caused by their competitors) to various bodies, especially the police (Wasilewski 2007, p. 95), which control them in terms of the legality of the operated activity, the possession of drugs, trafficking of alcohol, cigarettes, weapons, the prostitution of minors, the prostitution of persons that are lost or being sought, as well as illegal immigrants, connections with criminal organizations, and procuring, the facilitation of prostitution, pimping, holding someone against their will and forcing them into prostitution. The agency managers with whom I talked also mentioned inspections carried out by other services and organizations. They concerned compliance with orders, e.g., sanitary and fire safety regulations in the operation of a business activity. The inspection takes place with the cooperation of representatives of the authorized bodies, including, among others: the Fire Service, Border Guards, the Tax Office, the National Labor Inspectorate, the District Sanitary and Epidemiological Station, or the Construction Site Inspector. However, actions undertaken by those services, mainly by the police, are hindered as long as the agency is run pursuant to legal provisions and the female workers do not give testimonies confirming the facilitation of prostitution or procuring. Hence, usually consequences of the performed inspections are only temporary difficulties in the agency's operation, reflected in financial loss, such as an order to renovate the premises to meet fire safety or OHS regulations.

They control and control, but really what they can do? What will they do to me, as the girls say that everything is okay, because everything is okay, no harm is happening to anyone. No girl ever went to the police. What will they do to me? At most, I need to do some renovation to determine the evacuation route, the firemen told me. That's it. Unnecessary confusion with this renovation, but that's all they can do to me. (Manager of an escort agency)

It must be stressed that the present form of Polish legal regulations regarding prostitution is acceptable to society. The lack of interest in other ways to regulate this phenomenon is also proved by the fact that there has been no discussion on this topic in Poland for many years. In practice, it means tacit permission for the operation of agencies that - as it seems - have become rooted in the landscape of Polish cities. It creates a unique situation where agencies operate relatively freely, despite the fact they are breaking the law. This state of a delicate balance is a result of consensus and quiet acceptance from all parties that influence this situation and its change. In this context, a researcher who is willing to perform studies in agencies and to publish their results may be seen as a threat.

\section{Challenges related to carrying out the research project}

The purpose of my research was to reconstruct how escort agencies work, not only at the organizational level, but also at the level of interactions between their workers and clients. The main data collection techniques which I planned to use were observations (Angrosino 2010) and unstructured interviews (Kvale 2004). Thanks to them, I wanted to reconstruct the meanings ascribed by the agency workers to their actions and to identify their ways of organizing work and dealing with the social stigma connected to such an activity. In order to achieve these goals, it was necessary to visit the premises and establish direct contact with their workers. However, carrying out the research involved numerous challenges and difficulties. They were a consequence, first of all, of the legal and social context of the escort agencies, and more broadly, prostitution in Poland. These two aspects influenced how I was perceived by the subjects and, as a result, how could I develop my role as a researcher. The difficulties I experienced were related to several areas of planning and carrying out research, among others the sampling, getting access, my safety during gathering data and ethics. 


\subsection{Sampling}

As a result of the law penalizing third parties (including the owners of escort agencies), escort agencies undertake actions to hide their real activities. Therefore, it was tough to locate all the agencies operating within the area of the city, then to select certain cases for the research and obtain their consent.

It must be stressed that during the period I carried out the research, there were no organizations (e.g. of street workers) in Lodz, which would operate among sex workers. Thus, I could not turn for their help in obtaining information about the specificity of the local sex business or establishing contacts with potential interviewees. However, the experiences of such organizations from other cities ${ }^{3}$ suggest that street workers usually find it difficult to walk into an agency. It happens despite potential benefits for the agency from cooperation with them (spreading STI prophylaxis knowledge among the workers or providing them with condoms). This proves the suspicious and inaccessible nature of this environment, where a lot of effort is put into protection from unauthorized guests from the outside.

I started the field stage of the study with reconnaissance (Hammersley and Atkinson 2000 , p. 48), making an attempt to locate the agencies and work out the best way of establishing contact with the subjects. Although many agencies employ advertisements (in the initial stage of the research, the predominant medium was small ads in the daily press; currently it is done on the Internet, on dedicated websites), for a person unfamiliar with the situation, it may be difficult to locate them. In my case, the best results were achieved through informal conversations with acquaintances that use the agencies' services. As a result, I created a map of such venues in Lodz. I marked it not only with locations but also with basic information about the agency (size, number of female workers, equipment and scope of services, and reputation), which I hoped would allow me to preselect and choose certain cases for my research. I was eager to study the whole spectrum of agencies in Lodz, but I also wanted to gain my first research experiences in an agency I perceived as relatively safe. I selected the agencies where I wanted to start the research on the basis of the opinions of clients who I had talked to. Clearly, this was not a representative sample of the clients' opinions on local agencies; thus, they were affected by errors (these are hard to estimate). The selection of agencies for the research was also limited by the scope of knowledge of my informers, which was not always complete or up-to-date. I needed to work intensively to verify the obtained information, and afterwards, during the subsequent stages of the research, to correct the choices that I had made.

Together with progress of the analysis, when I differentiated various escort agencies' management styles (Ślęzak 2016), a problem emerged regarding gaining access to those that are managed in an oppressive manner. According to the principles of theoretical sampling (Glaser and Strauss 1967, Strauss and Corbin 1990), they should fall within the range of researched places. On the other hand, several other factors were a barrier. One of them was my security as a researcher. Based on the information obtained during the interviews with sex workers who had worked in those agencies previously, I knew that their managers kept women and forced them to provide sex services, and they kept the money the women earned. In such a situation it was impossible to conduct open observations. I did not decide to carry out the research in a covert manner, by, e.g., taking the role of a new worker. Undertaking such actions would be too dangerous in my view. During the period of the research, as a result of operational actions by the police, one of the facilities was closed, and its managers were arrested. In such a situation, the only source of information about that facility was the sex workers. However, they were not too open in discussing

\footnotetext{
${ }^{3}$ Informal discussions with street workers from such organizations operating in other cities lead to such a conclusion.
} 
issues related to that agency until the end of the legal process. This was the case regardless of whether they participated actively in the trial as witnesses or not.

\subsection{Access}

The greatest challenge I encountered was gaining access to the research area. Numerous researchers who have carried out empirical studies on sensitive topics admit that they needed much more time than they had planned for the stage of entering the world of the subjects (Sandberg and Copes 2013, p. 181). It was similar in my case. In hindsight, and on the basis of the interviews, I can stress several main reasons for the unwillingness to cooperate.

One of them was the image of the researcher in the eyes of the agency's managers. They were afraid that the information collected about the agency might be used against it for the researcher's own benefit. ${ }^{4}$ Of course, potentially, each person working in an agency can do this, but in practice it does not happen, because the people involved in sex work, if they are willing to carry on with it, do not undertake actions against their workplaces. It would mean not only trouble for the given agency, but it could also exert an adverse influence on the whole local market of sex services and narrow down the earning possibilities of a given person. Therefore, even if bad things are going on in the agency (e.g. violence), the female workers tend to leave the premises and look for another one, organized in a better manner, rather than informing the media or reporting it to the police. Police statistics prove (Marczewski 2014) that sex workers rarely report the fact that agency owners are breaking the law. Even fewer workers give testimonies (or they do not recall them) or participate in law suits if they are carried out. Unfortunately, this fact is used by agency managers, who often behave improperly (e.g. using violence) towards the female workers, unafraid of any consequences. However, a researcher present in the agency breaks this delicate arrangement, because he/she is a person from the outside, unrelated to the agency, without the interdependencies which would tell him/her to protect the agency's interests. Therefore, the presence of the researcher is perceived as a threat both at the stage of data collection and dissemination of the research findings. Although scientific articles and books usually have a limited circle of readers from outside the world of science, through the media they may reach the wider public. It is the duty of the researcher to delete data indicating the identity of the interviewees or the place of the research. However, drawing attention to the sex business world may render it more difficult to function on the border of legality. It may also change the perception of this world, showing the mechanisms of its operation which are hidden under the concept of erotic fun presented to the clients (and, to some extent, also the candidates or the female workers). From this perspective, the less knowledge and the more myths and stories about the agencies, the better for the owners.

The hesitation of the agencies' managers towards my presence also arose from fear of the consequences of the research for the premises in the context of their employees and clients. My presence, and above of all my questions, may deter clients from visiting the agency, where discretion is a must. The interviews may also cause problems with the sex workers. On the one hand, the bosses of the agencies could be afraid of what the female employees would say during the interviews, whether they would say something they should not (e.g. about the way the agency works). On the other hand, my presence and, most of all, the conversations with the female workers may be perceived as a threat for the self-esteem of the interviewees. Because of the stigma associated with sex work, they often feel anxious about meeting a "normal" (Goffman 1963, p.5), a person from outside the agency world. They are afraid that they will be judged and condemned by a researcher who does not understand their choices (Ślęzak 2013). It may incline the agency managers to

\footnotetext{
${ }^{4}$ What is interesting is that managers of escort agencies were mostly afraid that I might be a journalist and would publish the obtained information in the media.
} 
reject cooperation with a researcher, not to expose the female workers to negative emotions which could influence their further readiness for work. Other, negative (from the perspective of agency managers) consequence of the research maybe the influence on the further behavior of the sex workers, e.g. conversations with the researcher may stimulate their self-reflection, encouraging them to leave or to change the way they work, etc. Thus, consent of the manager of the agency to conduct the research may be risky in many dimensions.

Regarding these difficulties anticipated by the respondents, it was extremely difficult to obtain consent to carry the research out in the agencies. After initial nonparticipant observation, I made an attempt to talk to the security workers of selected premises, in order to negotiate conditions for access. However, my endeavors were met with indifference, suspicion, caution or even hostility. After eight months of the research reconnaissance (cf. Hammersley and Atkinson 2000, p. 48) I had not managed to establish a single contact which would result in the possibility of running an interview. A breakthrough moment in carrying out the project was, with help of friends, meeting a man who enabled access to the first escort agency, and to carry my research out there. He was a trusted friend of one of the agency's owners. With his help and my reassurances that I would not bring any trouble to the agency, I gained an opportunity to get into the premises and, afterwards, permission to remain there and carry out my research, firstly conditional and later full. ${ }^{5}$ However, it does not mean that the stage of data collection ran smoothly. There were attempts to hide certain topics and the agency's fields of operation from me. Such topics included, among others, the principles of employing women, settling up with them, storing money, but also allowing the workers to use psychoactive substances. Another taboo was the local connections between the agencies, the owning of several agencies by a single person, and how they are managed. Forbidden topics, therefore, mainly concerned activities that would allow the agency managers to be accused of benefiting from or facilitating the provision of sex services. I succeeded in collecting some of the information of my own, thanks to my long-standing presence in the premises and observations of various and spontaneous situations, which showed what is behind the scenes. I was able to explore the secrets of the owners' art thanks to unique data which also came out in the interviews with the female workers. It was possible because they assumed that, since the owners had agreed to my presence, they were free to talk about matters otherwise hidden.

In the case of my research, the key to gaining access was to gain trust, first of the agency manager, later the employees. However, to be able to work it out myself, it was necessary to borrow trust at the initial stage of the research. Invaluable was the help of a third party who introduced me to the agency and guaranteed my behavior. The trust he enjoyed opened the agency's door for me and gave me a chance to establish a rapport with the workers (more in: Ślęzak 2018).

\subsection{Researcher's safety}

The fact that the escort agencies operate on the margin of legality has consequences for the safety of the researcher. The literature presents many recommendations and good practices, which include, among others, instructions that while researching the sex business world, not to go into the field on your own, to work according to a previously arranged plan, and to communicate information regarding current problems to the remaining members of the team. It is also advisable to use the advice and help of others (e.g. social services, police) [Boynton 2002, p. 8]. In my case, I carried the research out on my own and there was no one with me in the agencies (apart from the initial period of being introduced, when I visited agencies with my gatekeeper). During my time in the agencies, if ever a dangerous situation arose, I could only count on help from the security guards. The police are perceived by the agency's workers as an external institution that cannot help in solving problems

\footnotetext{
${ }^{5} \mathrm{I}$ applied an analogical procedure of conduct in the remaining agencies as well.
} 
occurring in the agency - what happens there needs to be solved there (Ślęzak 2017). Thus, I was aware that if I did not want to lose my contacts, I should not call the police in the case of a dangerous situation. Fortunately, I did not need to make such a decision while carrying out the research, however, the concern about my security influenced my actions in the field, resulting in, e.g., attempts to establish friendly relationships with the security workers so I could get more care from their side. Moreover, I based my feeling of security on the person who introduced me to the premises - as a friend of the boss's friend, I was someone who should not experience anything bad while at the agency. However, while thanks to the established relationships I did not feel any threat from the side of the agency workers, the situation looked quite different in the case of interactions with the clients. They were not informed about the research and presumed that I was one of the female workers waiting for sex offers. Despite the fact that my clothes, make- up, ${ }^{6}$ conduct (I did not provoke interactions with the clients) differed from the other women in the agencies, it happened numerous times that clients established interactions with me in a manner typical for that space (e.g. verbal taunts, jokes with an erotic subtext). Apparently, they perceived and treated me like one of the sex workers. The majority of such interactions ended with my rejection of a sex meeting, but some men were more insistent and tried to convince me to change my mind. ${ }^{7}$ Obviously, the security workers supported me in such situations, but their work was not about watching me, but taking care of all aspects of the agency's operations. Therefore, it happened that when the number of clients was high, and there were plenty of difficult clients ${ }^{8}$ at the same time, the security workers responded with some delay, and I felt so uncomfortable that I decided to remain only in the area not accessible to the clients, or I stopped the observation and left the agency.

\subsection{Ethical dilemmas}

My priority, both during the research and afterwards, when the results were published, was to take care not to expose the interviewees to any problems that would arise from their participation in the project. An analogical principle considers the presentation of the data on the researched facilities which also results from my arrangements with the managers. In return for their help, they expected my loyalty and the promise that any issues that might be of interest to the law enforcement bodies would remain confidential (c.f. Sanders 2006, p. 455). To obtain the consent for the research in a given facility I undertook to protect my informers. It means protection of data on the operation of the facilities that violate the Polish law. In the case of the agencies that I researched, and which were managed professionally (Ślęzak 2016), these actions resulted from efforts not to harm the workplaces of my interviewees. They were good workplaces from their perspective, where they did not encounter violence or exploitation, and I would not like my actions to threaten the stability of the agency's operations in any manner. Bearing in mind the fact that I cannot provide the researched women with an alternative job to prostitution, I came to the conclusion that I had no right to risk them losing the way they earn a living that they approve of. This choice would not be so obvious in the case of oppressively managed agencies, especially if I witnessed violence towards the female sex workers. Fortunately, I did not witness any incidents that would require intervention from the police during my research, but stories about such situations (in the form of memories of working in other agencies or stories about friends' experiences) appeared in the interviews quite frequently (Ślęzak 2016). It meant that during the course of the

\footnotetext{
${ }^{6}$ I carried out the observations within the agency in my ordinary clothes; I also did not change my hair or makeup. It was purposeful, as I did not play the role of a female worker there.

7 This suggests indirectly the manner in which the sex female workers are perceived by the clients. Many of them believe that the price is the only variable intervening in the course of interactions, and they do not accept the fact that a sexual relationship may be rejected.

${ }^{8}$ A difficult client is a client who needs more attention from security staff, e.g. aggressive, under the influence of alcohol or drugs.
} 
study I felt constant uncertainty, wondering what I would see during the observation and how I should react to it.

\section{Discussion}

My research experience described above was closely related to the context of the study. Several key elements influencing its course can be distinguished. One of them is the system of legal regulation of prostitution in Poland. The researcher's possibilities, limitation and threats may be different if clients or sex workers are criminalized in a given state, or when prostitution is legal there. Also the demand for studies (e.g. for particular research topics) looks different in various legal contexts. The researcher's responsibility may be different as well, as the results can be used as arguments in discussions on changing the law. Thus, studies carried out in various legal contexts may cause various consequences for those who are being researched. During my research, there were no debates in Poland (they are still not taking place at the time of writing, 2018) on changes in the law regarding prostitution. Furthermore, the discussions that were taking place in Europe and around the world (e.g. in France, Germany, the United Kingdom, in the forum of the European Parliament, in Canada, or the United States) at that time were almost unnoticed in the Polish discourse, and they did not pose any important point of reference for legislators, politicians, or, quite often, even for the researchers. However, in countries where the discussion of legal changes relating to prostitution is much more intensive, the studies' results are an important argument in discussions on the evaluation of existing solutions and their modifications. A lot is being written about the consequences of introducing the so-called "Swedish model" in numerous countries (e.g. Scoular 2010, Levy and Jakobsson 2014) or the benefits of decriminalizing prostitution (among others, a special issue of The Lancet stressed the significance of decriminalization increasing the safety of sex workers in the context of the risk of HIV - see Das et al. 2014 -; there were also articles presenting the consequences of decriminalizing prostitution in New Zealand, Abel et al. 2007, 2009, Abel 2014). Comparative studies that analyze the consequences of introducing various legal regulations in particular countries are also highly interesting (Scoular 2010). Thanks to such works, a researcher may become an active member of not only the scientific discourse but of a wider debate regarding directions of legal changes.

Secondly, my research was of an academic character. I carried out the project in accordance with the guidelines of the grounded theory methodology (Glaser and Strauss 1967, Strauss and Corbin 1990). This means that the research questions, hypotheses and theoretical framework resulted from the logic of the research process and analysis of the collected data. Meanwhile, numerous studies on prostitution are developed at the request of various organizations or state governments. Some of them are created in a clearly defined ideological context, as an element in the argument for or against a specific model for regulating prostitution. ${ }^{9}$ The studies are often criticized because of their low quality. Weitzer states: "In no area of the social sciences has ideology contaminated knowledge more pervasively than in writings on the sex industry. Too often in this area, the canons of scientific inquiry are suspended and research deliberately skewed to serve a particular political agenda" (Weitzer 2005, p. 934). The notions stressed by Weitzer force a researcher to face an especially significant problem to clearly define their opinion on prostitution and various models of its regulations (and highlight it in published works). They also draw attention to the need to preserve scientific reliability in the face of a variety of

\footnotetext{
9 An example might be the Report on Prostitution and Sexual Exploitation and its Impact on Gender Equality, by Mary Honeyball (2014). It recommends introducing a legal model that would criminalize clients using sex services (the so-called "Swedish model"). This report encountered crushing criticism from individuals and associations acting to the benefit of sex workers. It was also criticized in an open letter signed by 94 scientists dealing with problems of sex work, who stressed its tendentiousness and methodological errors. Despite that, the ideological spread of the report was so strong that it was approved by the Committee on Women's Rights and Gender Equality (FEMM), and on 26.02.2014 it was adopted by the European Parliament.
} 
collected data, even if they are not necessarily compliant with the researcher's perspective (e.g. they contradict their private views). These notions may be especially important and difficult in case of commissioned research.

The researchers' possibilities are also influenced by the level of the support organization networks (mainly NGOs), the scale of their operations and the scope of help and acceptance in the sex workers' environment. Their presence in a given city changes the climate around this phenomenon and provides new opportunities to carry out research. The more the organizations are rooted in a given territory and accepted by the sex workers, the greater the researcher's chance for positive cooperation in the scope of help in establishing relationships in the field and acquiring new participants for the studies (c.f. Sanders et al. 2018). This is important, as according to Shaver, the basic problem in researching sex work is the selection of the sample and the validity of the data (Shaver 2005). The assistance provided by organizations that operate among sex workers while recruiting participants of studies may be a contributing factor to building trust. A researcher who is an outsider somehow borrows the trust from a given organization and gains the opportunity to establish a rapport with the interviewees (c.f. Sanders, Connelly and Jarvis-King 2017). Visiting the field in the company of street workers may also have a positive influence on the researcher's safety and emotional comfort. The researcher can use their support network, clues and help, which is very important as street workers often have broader experience in dealing with sex workers than the researcher. They may also provide help in the case of legal dilemmas. However, it should be mentioned that cooperating with organizations may also have some drawbacks. They include (c.f. Angrosino 2010): narrowing down the studied population to the beneficiaries of the organization; making access to those groups that do not accept the organization more difficult; and tensions related to establishing the level of impact of the organization on the research. These issues should be taken into account when designing the study.

It must also be stressed that numerous researchers, influenced by stories of the researched women, change their emotional attitude towards prostitution, and become activists for the benefit of the researched persons. They get involved in the work of existing organizations or they co-create new ones. These actions adopt various shapes in practice - regarding the researcher's beliefs. For some of them, such an activity is a way to deal with the feeling of helplessness that accompanied them during the project, or feeling guilty that they used the respondents (Dec and Szumigraj 2004, Bernstein 2007, p. 196, Dickson-Swift et al. 2007, p. 340).

As I have already mentioned I did not have an opportunity to cooperate with such organizations, therefore, my research experiences might not be completely compliant with the experiences of other researchers using such help.

\section{Summary}

The social, legal and cultural context of the operation of escort agencies in Poland influences the manner in which the research is carried out. Despite the abolitionist character of the current legal regulations, which do not penalize those providing the sex services or their clients, both groups are rather reluctant to participate in the studies. In the case of my research, the attitudes most typical for people running the agencies included distance, refusing to participate, and hindering the carrying out of the research (despite the provided consent).

The difficulties described above may be overcome if the researcher succeeds in encouraging the agency workers to cooperate, so they feel motivated to be open, despite the potential threats related to their participation in the research.

The proper selection of the organization (and therefore having some knowledge about the local sex business) and finding an effective way to enter it, and then establishing a rapport with the interviewees, seems to be crucial for the commencement of the 
study. Initially, I lacked the trust of the respondents, who perceived me as a threat and an intruder. Because of their distrust, they also did not have a chance to change their ideas about me in direct interactions. Because of this, I experienced repeated research failures. In the situation of a lack of trust, it was effective to borrow it from a person who enjoyed it in the studied world. My gatekeeper (Hammersley and Atkinson 2000) vouched for me with his reputation, which opened the door of the agencies for me (Ślęzak 2018). On the other hand, I became responsible for not destroying the good position of the agencies in the studied environment. In the later period of research, gaining trust of the subjects was possible thanks to my own actions. It was achieved through personal relationships with the interviewees, developed through presence, skillful conversation, the attitude of not judging and not criticizing their life choices, and confirming it not only with words, but mainly with actions proving that I was not a threat to the agency's existence or the security of its workers. The trust I was given was therefore not based on professional affiliation or a CV, but on direct contact, observing me, and verifying it in multiple interactions. Obviously, it is easier to achieve such a position if, as in my case, one is introduced into the organization by a person who is already trusted by the agency's owner. On the basis of my experiences, I may put forward a hypothesis that it is a necessary condition to be able to carry out long-standing ethnographic research in this environment. This is true especially since sex workers in Poland do not get involved in the operation and establishment of organizations which would represent their perspective and fight for their rights in the international arena. ${ }^{10}$ As demonstrated by examples of studies carried out in other countries where such organizations operate, they may encourage its members to get involved in scientific projects (c.f. Sanders et al. 2018). Therefore, they provide invaluable support for the researcher. Although such cooperation may cause other dilemmas (e.g. the interdependence between the objectives of particular organizations and the quality of the obtained data), the analogical biases may also be an effect of cooperating with any other entity introducing the researcher into the area.

A crucial factor in facilitating the process of conducting research in this environment would be a change in the social perception of sex workers, potentially reflected in possible changes in the law, towards solutions that would decriminalize sex services. However, the chances for such a change occurring in Poland in the nearest future seem to be minuscule.

\section{References}

Abel, G.M., 2014. A decade of decriminalization: Sex work "down under" but not underground. Criminology and Criminal J ustice [online], 14 (5), 580-592. Available from: http://journals. sagepub.com/doi/abs/10.1177/1748895814523024 [Accessed 7 J une 2018].

Abel, G.M., Fitzgerald, L.J., and Brunton C., 2007. The Impact of the Prostitution Reform Act on the Health and Safety Practices of Sex Workers: Report to the Prostitution Law Review Committee [online]. November. Department of Public Health and General Practice. Christchurch: University of Otago Press. Available from: https://www.otago.ac.nz/christchurch/otago018607.pdf [Accessed 7 June 2018].

Abel, G.M., Fitzgerald, L.J., and Brunton, C. 2009.The impact of decriminalisation on the number of sex workers in New Zealand. Journal of Social Policy [online], 38 (3), 515-531. Available from: http://citeseerx.ist.psu.edu/viewdoc/download?doi=10.1.1.170.3113\&rep=rep 1 \&type=pdf [Accessed 7 J une 2018].

\footnotetext{
${ }^{10}$ The first such type of action is the coalition Sex Work Poland (https://sexworkpolska.wordpress.com/)
} 
Angrosino, M., 2010. Badania etnograficzne i obserwacyjne. Warszawa: Wydawnictwo Naukowe PWN.

Atkinson, P., et al., eds., 2001. Handbook of Ethnography. London: Sage.

Bernstein, E., 2007. Temporarily Yours. Intimacy, Authenticity, and the Commerce of Sex. University of Chicago Press.

Boynton, P.M., 2002. Life on the streets: the experiences of community researchers in a study of prostitution. Journal of Community \& Applied Social Psychology [online], 12 (1), 1-12. Available from: https://doi.org/10.1002/casp.657 [Accessed 7 J une 2018].

Convention for the Suppression of the Traffic in Persons and of the Exploitation of the Prostitution of Others [online]. Approved by General Assembly of the United Nations resolution 317 (IV) of 2 December 1949. Available from: http://www. ohchr.org/EN/Professionall nterest/Pages/Trafficl nPersons. aspx [Accessed 7 June 2018].

Criminal Procedure Code of the Republic of Poland. Act of 6 J une 1997, amended 2003 [online]. Available from: http://www.legislationline.org/documents/section/criminal-codes/country/10 [Accessed 7 June 2018].

Das, P., et al., 2014. The Lancet Series: HIV and sex workers. The Lancet [online], 385 (9962-9964). Available from: https://www.thelancet.com/series/HIV-andsex-workers [Accessed 7 J une 2018].

Dec, J., and Szumigraj, E., 2004. Swoisty charakter pomocy osobom świadczącym usługi seksualne. In: E. Siarkiewicz, red., Niejednoznaczność poradnictwa. Zielona Góra: Oficyna Wydawnicza Uniwersytetu Zielonogórskiego, 99-107.

Dickson-Swift, V., et al., 2007. Doing sensitive research: what challenges do qualitative researchers face? Qualitative Research [online], 7 (3), 327-353. Available from: http://journals.sagepub.com/doi/abs/10.1177/1468794107078515 [Accessed 7 J une 2018].

Glaser, B., and Strauss, A., 1967. The Discovery of Grounded Theory. Strategies for Qualitative Research. New York: Aldine de Gruyter.

Goffman, E., 1963. Stigma. Notes on the Management of Spoiled Identity. Englewood Cliffs, NJ: Prentice-Hall.

Hammersley, M., and Atkinson, P., 2000. Metody badań terenowych. Poznań: Wydawnictwo Zysk i S-ka.

Honeyball, M., 2014. Report on sexual exploitation and prostitution and its impact on gender equality (2013/2103(INI)). A7-0071/2014 [online]. European Parliament, Plenary sitting of 4 February. Available from: http://www. europarl. europa. eu/sides/getDoc.do?pubRef=//EP//NONSGML+REPORT+A7-2014-0071+0+DOC+WORD+V0//EN [Accessed 7 J une 2018].

Kleinknecht, S., 2007. An interview with Robert Prus: his career, contributions, and legacy as an interactionist ethnographer and social theorist. Qualitative Sociology Review [online], 3 (2). Available from: http://www.qualitativesociologyreview.org/ENG/Volume7/QSR_3_2_Kleinknec ht.pdf [Accessed 10 October 2007].

Kozłowska-Kalisz, P., and Nazar-Gutowska, K., 2014. Doprowadzenie innej osoby do uprawiania prostytucji (art. 203 k.k.). In: M. Mozgawa, red., Prostytucja. Warszawa: Wolters Kluwer, 95-116. 
Kvale, S., 2004. InterViews. Wprowadzenie do jakościowego wywiadu badawczego. Białystok: Trans Humana.

Levy, J., and Jakobsson, P., 2014. Sweden's abolitionist discourse and law: Effects on the dynamics of Swedish sex work and on the lives of Sweden's sex workers. Criminology and Criminal Justice [online], 14 (5), 593-607. Available from: http://journals. sagepub.com/doi/abs/10.1177/1748895814528926 [Accessed 7 J une 2018].

Marczewski, M., 2014. Przestępstwa związane z prostytucją w świetle statystyki policyjnej i sądowej. In: M. Mozgawa, red., Prostytucja. Warszawa: Wolters Kluwer, 307-320.

Marek, A., 2010. Kodeks karny. Komentarz. Warszawa: Wolters Kluwer.

Piórkowska-Flieger, J., and Wala, K., 2014. Tak zwane przestępstwa okołoprostytucyjne (art. 204 k.k.). In: M. Mozgawa, red., Prostytucja. Warszawa: Wolters Kluwer, 72-94.

Prus, R., and Irini, S., 1988. Hookers, Rounders and Desk Clerks. The Social Organization of the Hotel Community. Reissued. Salem, WI: Sheffield.

Radecki, W., 1968. Sytuacja prawna prostytucji w Polsce. Problemy Kryminalistyki, 73, 344-362.

Reckless, W.C., 1925. The Natural History of Vice Areas in Chicago. University of Chicago Press.

Reckless, W.C., 1933. Vice in Chicago. Chicago University Press.

Sandberg, S., and Copes, H., 2013. Speaking with ethnographers: the challenges of researching drug dealers and offenders. Journal of Drug Issues [online], 43 (2), 176-197. Available from: http://journals. sagepub.com/doi/abs/10.1177/0022042612465275?journalCo de=joda [Accessed 7 J une 2018].

Sanders, T., 2006. Sexing up the subject: methodological nuances in researching the female sex industry. Sexualities [online], 9 (4), 449-468. Available from: http://journals. sagepub.com/doi/abs/10.1177/1363460706068044 [Accessed 7 J une 2018].

Sanders, T., Connelly L., and Jarvis-King L., 2017. On Our Own Terms: The Working Conditions of Internet Based Escorts in the UK. Sociological Research Online, 21 (4), 15. Available from: http://www. socresonline.org.uk/21/4/15.html [Accessed 7 J une 2018].

Sanders, T., et al., 2018. Internet Sex Work: Beyond the Gaze. London: Palgrave Macmillan.

Scoular, J., 2010. What's law got to do with it? How and why law matters in the regulation of sex work. Journal of Law and Society [online], 37 (1), 12-39. Available from: https://doi.org/10.1111/j.1467-6478.2010.00493.x [Accessed 7 J une 2018].

Shaver, F.M., 2005. Sex work research: methodological and ethical challenges. J ournal of Interpersonal Violence [online], 20 (3), 296-319. Available from: https://doi.org/10.1177/0886260504274340 [Accessed 7 J une 2018].

Ślęzak, I., 2013. Refleksje nad zagadnieniem piętna w relacjach badacza i badanych na podstawie wywiadów z kobietami świadczącymi usługi seksualne. Nauka i Szkolnictwo Wyższe [online], 1 (41), 149-162. Available from: https://tinyurl.com/y7kszfvs [Accessed 7 J une 2018].

Ślęzak, I., 2016. Praca kobiet świadczących usługi seksualne w agencjach towarzyskich. Łódź: Wydawnictwo Uniwersytetu Łódzkiego. 
Ślęzak, I., 2017. Violence towards Sex Workers. Analysis Based on Research into the Field of Indoor Sex Work in Poland. Polish Sociological Review [online], 198 (2), 237-254. Available from:

https://www.researchgate.net/publication/318909800_Violence_towards_sex workers_Analysis based_on research into the field_of_indoor_sex_work in Poland [Accessed 7 J une 2018 ].

Ślęzak, I., 2018. Praca nad zaufaniem. Etyczne, praktyczne i metodologiczne wyzwania w relacjach badacz-badani na przykładzie etnografii agencji towarzyskich. Przegląd Socjologii Jakościowej [online], 14 (1), 138-162. Available from: http://dx.doi.org/10.18778/1733-8069.14.1.07 [Accessed 7 June 2018].

Strauss, A., and Corbin, J., 1990. Basics of Qualitative Research. London: Sage.

Wasilewski, J., 2007. Wykorzystanie materiałów operacyjnych uzyskanych od przedstawiciela MSW Ukrainy dotyczących handlu ludźmi w kierunku eksploatacji seksualnej na terenie Wielkopolski i przekształcenie ich w materiał procesowy. In: J. Bryk, I. Malinowska, red., Walka z handlem Iudźmi w aspekcie współpracy międzynarodowej. Polsko-ukraińska wymiana doświadczeń i umiejętności praktycznych. Materiały pokonferencyjne. Szczytno: Wydawnictwo Wyższej Szkoły Policji.

Weitzer, R., 2005. Flawed Theory and Method in Studies of Prostitution. Violence against Women [online], 11 (7), 934-949. Available from: http://citeseerx.ist.psu.edu/viewdoc/download?doi=10.1.1.170.3117\&rep=rep 1\&type=pdf [Accessed 7 J une 2018]. 